\title{
Perceptions of Faculty Status among Academic Librarians
}

\section{Quinn Galbraith, Melissa Garrison, and Whitney Hales}

This study measures the opinions of ARL librarians concerning the benefits and disadvantages of faculty status in academic librarianship. Average responses from faculty and nonfaculty librarians, as well as from tenured and tenure-track librarians, are analyzed to determine the general perceptions of each group. Overall, faculty librarians reported more positive perceptions of faculty status than nonfaculty librarians. Tenured librarians generally reported more positive perceptions than tenure-track librarians. Despite the differences in opinion, these results offer insight into the potential benefits and disadvantages of faculty status in academic librarianship and suggest that faculty status improves relationships with teaching faculty, even if status alone cannot make them full peers.

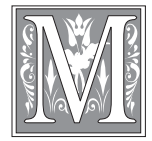

any articles have discussed the pros and cons of granting librarians faculty status and tenure. This is perhaps one of the most heated debates in the field of academic librarianship, as the effectiveness of the faculty status model in librarianship has been both ruthlessly questioned and valiantly defended by numerous librarians. However, library science literature generally makes subjective assumptions about the pros and cons of the faculty status argument, relying on author opinion rather than exploring the relevancy of faculty status to librarians and librarianship as a whole. This leaves open the possibility that the literature reflects the opinions of individuals and may be far removed from the concerns of librarians overall. As of yet, there have been no attempts to determine the extent to which these opinions reflect the thoughts of any collective group of librarians. This study attempts to measure the strength of librarians' perceptions regarding key points in the faculty status argument, which may allow administrators to understand their employees' perceptions and make more thorough policy decisions. While there are many points of discussion in this study, the central point is how faculty status influences librarians' relations with teaching faculty.

\section{Literature Review}

Literature discussing librarian faculty status is extensive, with most commentators coming across as decidedly for or against faculty status. Much of this dialogue centers

Quinn Galbraith is Sociology and Family Life Librarian, and Melissa Garrison and Whitney Hales are Research Assistants in the Harold B. Lee Library and Brigham Young University; e-mails: quinn_galbraith@byu.edu, melissa_garrison@byu.net, and whitney.hales674@gmail.com. We appreciate the assistance of Sean Miner, Statistics Research Assistant at Brigham Young University. (C) 2016 Quinn Galbraith, Melissa Garrison, and Whitney Hales, Attribution-NonCommercial (http://creativecommons.org/licenses/by-nc/3.0/) CC BY-NC. 
on whether or not faculty status hinders the functions of librarianship, questioning if research expectations keep librarians from assisting patrons. In a poignant article, Blaise Cronin criticizes librarian faculty status as an "obsession" that "merely detracts from customer service." ${ }^{1}$ As supporting evidence, Cronin cites Kingma and McCombs, who "discovered that professional productivity and faculty status were negatively correlated." ${ }^{2}$ However, other scholars argue that faculty status and its associated research expectations enable librarians to provide superior service. Shalu Gillum cites Fennewald, who found that "academic librarians with faculty status felt that their research...improved services." ${ }^{3}$ Gillum concludes that "research performed by librarians in their scholarly writing process actually helps them with their daily problem solving, which translates into better customer service." 4

While considering the faculty status debate, we must also determine how librarians' research contributes to the academic arena. Many critics question whether librarians are capable of producing quality research on the same level as teaching faculty. For example, Paul Alan Wyss points out that librarians typically hold a master's degree, while teaching faculty generally have PhDs. ${ }^{5}$ Mary Biggs widens this educational gap by arguing that the MLS does not adequately prepare librarians for research because courses "are taught not at a level of sophistication that presupposes considerable previous training, but at a beginning level." ${ }^{\prime 6}$ Even Janet Swan Hill, an author who enthusiastically supports faculty status, admits that a library science education "rarely prepares [librarians] well to think of themselves as faculty or to understand what being faculty entails." 7 However, a quantitative study by Quinn Galbraith et al. found that the majority of articles published in high-impact library science journals were authored by librarians with faculty status and that the majority of the faculty librarians publishing were in tenure-track positions. ${ }^{8}$ Even more interestingly, W. Bede Mitchell and Mary Reichel conclude that "tenure-track librarians are meeting tenure standards at the same or higher rate as instructional faculty." As such, we may accept that most librarian faculty members can hold their own when conducting and publishing research.

Another central facet of the argument lies in how librarians' faculty status may affect their relationship with the teaching faculty. If there is a strong relationship between the two groups, then teaching faculty may feel more comfortable partnering with librarians to fully use library resources in their classrooms and research pursuits. However, many scholars feel that faculty status is not enough to foster positive relationships between teaching faculty and librarians. Beth J. Shapiro argues that "faculty status does not ensure that librarians will be considered equal partners in the educational process." ${ }^{10}$ Instead, she proposes that "respect and status must be earned by developing our libraries into excellent, responsive units on campus that provide essential support to the teaching and research mission of the university."11 Still, awarding faculty status to librarians may improve the teaching faculty's estimation of their colleagues in the library. Devin Feldman and Susan Sciammarella found that " 84 percent [of librarian respondents in their study] felt that recognizing them as...faculty would help improve the status of the librarian in the academic community." 12 As this occurs, other benefits may be anticipated - Wade R. Kotter asserts that "classroom faculty who feel good about the library and librarians will be more likely to encourage their students to use the library." ${ }^{13}$ Kotter further claims that "most students use library services only when they are encouraged or required to do so by their instructors." ${ }^{14}$ With these compelling implicit benefits at stake, it is important to assess how faculty status can influence a librarian's status on campus.

While this study focuses on perceptions rather than factual evidence, librarians' perceptions may offer valuable insight. Why? Jacalyn Bryan cites Werrell and Sullivan, who acknowledge that faculty status contributes to "librarians' image of themselves as educators," perhaps even "with scholarly interests and knowledge on a par with those 
of the teaching faculty."15 Biggs suggests that "tangible benefits are a strong motivation for seeking faculty status, but another is its symbolic, psychological significance" centering on perception and self-image. ${ }^{16}$ The paper by Catherine Coker et al. argues that, "Faculty status offers librarians a series of protections both tangible and psychological." 17 Similarly, Bernstein claims that "the preeminent psychological components of faculty classification may be less overt than the material factors...but are no less significant." ${ }^{18}$ Bernstein also contends that faculty status influences the "sense of commitment both to the institution and the library profession, as well as the facilitating of a higher level of involvement with the educative mission of both the library, specifically, and the college or university, generally." 19 Other researchers - similarly feeling that perception can strongly influence outcomes in the library - have recently published studies and articles treating librarian perception. ${ }^{20}$ Because librarians feel so strongly about faculty status, it is important for institutions to refer to their perceptions when discussing faculty status and making decisions.

\section{Methodology}

Researchers contacted the library administrators of 110 English-speaking ARL libraries via e-mail to distribute a survey. A total of twenty-five libraries opted to participate in the survey. Fifteen of these libraries offered faculty status and tenure to librarians; eight offered neither faculty status nor tenure; two offered faculty status but not tenure. The library administrators distributed the survey to their peers, who had a defined window of time if they wished to participate. Since terminology varies between institutions, each library was responsible for reporting if their policies equated to "faculty status" and/ or "tenure." For the purposes of this study, the term "faculty status" refers to granting academic librarians the same entitlements and rights as teaching faculty. According to ACRL, faculty status may include "corresponding entitlement to rank, promotion, tenure, compensation, leaves, and research funds." ${ }^{21}$ Drawing from Shalu Gillum's definition, we recognize that "at some institutions, faculty status refers to academic rank (such as Librarian I, II, or III) and the same rights and privileges of teaching faculty, whereas at others it represents the availability of tenure." 22 In this case, tenure is defined as "continuous appointment or a commitment by an institution to provide permanent employment where one can only be terminated for adequate cause."23

The survey distributed to these ARL libraries began with a series of questions regarding the librarian's history, rank, and faculty status/tenure (as applicable) at his or her present institution. It continued with four questions asking the librarian to rate measures of employee well-being (like stress levels and work-life balance) on a scale of 1-7, with 7 representing high well-being. The survey then asked librarians to rate their level of value or agreement when presented with different arguments surrounding the faculty status debate. The responses to these 36 questions were recorded on a Likert scale of $1-7$, with 7 representing strong agreement or value. In addition, two free-response questions asked for additional comment or clarification. The first free-response question was administered halfway through the series of value and agreement statements, while the second was the last question of the survey (see appendix A). The Institutional Review Board at Brigham Young University approved the survey and each of its questions.

Survey questions varied slightly in wording between certain institutions - namely, pronouns differed based on whether the library in question offered its librarians faculty status. Surveys sent to faculty institutions addressed librarians' personal experiences with faculty status by using personal pronouns, like in "Faculty status gives me the opportunity to gain the respect of teaching faculty." For nonfaculty institutions, personal pronouns were replaced with "librarians," like in the corresponding question "Faculty status gives librarians the opportunity to gain the respect of teaching faculty." 
A total of 846 librarians responded to the survey; however, since there is no way to tell how many librarians received the survey e-mail, a response rate could not be calculated. Individual responses were eliminated when respondents did not answer the individual question being analyzed or when they did not report demographic information. In addition, the 62 responses from libraries with faculty status but without tenure were excluded from analysis and discussion. Since the majority of ARL libraries offer both faculty status and tenure or offer neither, this group is exceptional, so their responses represented only a small portion of ARL libraries. ${ }^{24}$ Further, these 62 responses varied from each other so much that they could not be considered representative of librarian opinion in general. After these exclusions, 719 responses remained and were analyzed as part of the results. Of the 719 respondents, 299 had faculty status and tenure, and 171 were tenure-track librarians (or working toward tenure). The respondents also included 158 nonfaculty librarians with more than six years of experience, and 91 nonfaculty librarians with fewer than six years of experience. At institutions that offer tenure to librarians, it takes six years to go through the tenure process, which is why six years is used as the comparison index between faculty and nonfaculty librarians. We will refer to the nonfaculty librarians with more than six years of experience as "experienced nonfaculty librarians" and the nonfaculty librarians with fewer than six years of experience as "less experienced nonfaculty librarians."

Responses between faculty and nonfaculty librarians were compared using a standard two-tailed, two-sample t-test whenever possible. When questions varied because of the wording differences between faculty and nonfaculty surveys, averages were reported without statistical analysis.

Researchers also compared responses from tenured and tenure-track librarians with a two-tailed, two-sample t-test. Their responses were further compared to the responses of both experienced and less experienced nonfaculty librarians. This ensured fair comparison among all librarian respondents in the study.

\section{Results}

\section{Personal Questions and Statements}

The survey included several questions relating to the respondents' opinions of faculty status (see table 1). When asked how important their faculty status is to them, faculty librarians responded with an average of 4.82 . (Please note that this average, like all others in the results and discussion sections, is reported out of 7.) Nonfaculty librarians were asked a corresponding question regarding how important faculty status would be to them; they responded with an average of 3.66. However, nonfaculty librarians did say that they place higher importance on faculty status for the library profession as a whole. This suggests that, even if nonfaculty librarians do not view faculty status as personally important, they appreciate its place in the librarian profession. In fact, their average response of 4.09 on the statement about the profession as a whole showed statistical significance when compared to their 3.66 on the personal statement $(p=1.19 \mathrm{E}-6)$. Librarians with faculty status showed no statistically significant difference between these two questions. Although these questions were worded too differently to be compared by t-test, when asked if faculty status - or the lack thereof - was a deciding factor in accepting their current position, faculty librarians showed average agreement of 3.83 compared to the 2.73 average nonfaculty response. These averages suggest that faculty librarians perceive that faculty status is more important than nonfaculty librarians do. 


\begin{tabular}{|c|c|c|c|c|c|}
\hline \multicolumn{6}{|c|}{$\begin{array}{c}\text { TABLE } 1 \\
\text { Personal Questions }\end{array}$} \\
\hline Group & Question & Average* & DF & $\mathbf{T}$ & $\mathbf{P}$ \\
\hline \multirow[t]{2}{*}{ Faculty } & $\begin{array}{l}\text { Personal Importance of Faculty } \\
\text { Status }\end{array}$ & 4.82 & \multirow[t]{2}{*}{455} & \multirow[t]{2}{*}{1.779} & \multirow[t]{2}{*}{0.0758} \\
\hline & Importance to Profession & 4.70 & & & \\
\hline \multirow[t]{2}{*}{ Non-Faculty } & $\begin{array}{l}\text { Personal Importance of Faculty } \\
\text { Status }\end{array}$ & 3.66 & \multirow[t]{2}{*}{246} & \multirow[t]{2}{*}{4.982} & \multirow[t]{2}{*}{$1.19 \mathrm{E}-06^{* * *}$} \\
\hline & Importance to Profession & 4.09 & & & \\
\hline
\end{tabular}

\section{Arguments for Faculty Status}

Several questions gauged librarian opinion on the potential benefits of faculty status (see table 2). To determine perceptions of the impact of faculty status on relations with teaching faculty, librarians were asked to what extent they agree with the statement "faculty status helps librarians earn the respect of teaching faculty." With averages of 4.23 and 4.31 , there was no statistically significant difference between faculty and nonfaculty responses. This suggests that most librarians agree that faculty status makes them more respectable in the eyes of the teaching faculty. One nonfaculty librarian wrote a free response that stated, "I can't help but feel we would get more respect from faculty and administration if we had faculty status." However, it is important to note that faculty and nonfaculty librarians gave significantly different answers to a similar statement: "The teaching faculty consider librarians peers because of library faculty status." While similar to the previous question, this question implies that teaching faculty already see librarians as their academic equals. Both faculty and nonfaculty librarians reported lower averages for this question. Nonfaculty librarians ranked an average agreement of 2.98, which was significantly lower than the faculty average of $3.46(p=7.38 \mathrm{E}-4)$. These averages suggest that librarians view faculty status as a step in the right direction in improving their relations with teaching faculty, even though it cannot make them peers.

Librarians with faculty status were presented with the statement "I have an increased opportunity to participate in university governance because of faculty status" and responded with an average agreement of 5.71. Librarians without faculty status responded with an average of 5.02 when shown the corresponding statement "Librarians with faculty status have an increased opportunity to participate in university governance." This question had the highest average response for both faculty and nonfaculty librarians, indicating strong agreement. Despite any differences between the two groups, each seems to acknowledge that faculty status has a positive impact on librarian participation in university governance. One faculty librarian succinctly explained that "faculty status means that librarians are present in venues and therefore able to influence policy and direction that directly influence our students. Without faculty status, we would not be present in many of these venues."

The survey included statements to capture librarians' perceptions on whether faculty status helps the library profession or not. For example, it asked librarians to rate their agreement with the statement "Faculty status helps librarians progress and develop professionally." The difference in responses was statistically significant, as librarians with faculty status agreed more strongly than did librarians without faculty status ( $p=1.12 \mathrm{E}-5)$. Additionally, faculty librarians showed significantly stronger agreement than nonfaculty when asked if faculty status provides opportunities and resources for 


\begin{tabular}{|c|c|c|c|c|c|c|c|c|}
\hline \multicolumn{9}{|c|}{$\begin{array}{c}\text { TABLE } 2 \\
\text { Arguments for Faculty Status }\end{array}$} \\
\hline & Question & Q45 & Q29 & Q27 & Q35 & Q24 & Q47 & Q18 \\
\hline & & $\begin{array}{c}\text { Earns Respect } \\
\text { of Teaching } \\
\text { Faculty }\end{array}$ & $\begin{array}{l}\text { Teaching Faculty } \\
\text { Consider } \\
\text { Librarians Peers } \\
\end{array}$ & $\begin{array}{c}\text { Participation } \\
\text { in University } \\
\text { Governance }\end{array}$ & $\begin{array}{c}\text { Professional } \\
\text { Development } \\
\text { and Progression } \\
\end{array}$ & $\begin{array}{l}\text { Opportunities } \\
\text { to Participate } \\
\text { in Scholarship }\end{array}$ & $\begin{array}{l}\text { Promotes } \\
\text { Publication } \\
\end{array}$ & $\begin{array}{c}\text { Beneficial } \\
\text { to Library } \\
\text { Patrons } \\
\end{array}$ \\
\hline \multirow{6}{*}{$\begin{array}{l}\text { Averages } \\
\text { (on Likert scale of 1-7) }\end{array}$} & All Faculty & 4.23 & 3.46 & 5.71 & 5.09 & 5.27 & 4.80 & 4.30 \\
\hline & All Non-Faculty & 4.31 & 2.98 & 5.02 & 4.51 & 4.15 & 4.26 & 3.51 \\
\hline & Tenure & 4.52 & 3.78 & 6.00 & 5.30 & 5.53 & 4.89 & 4.73 \\
\hline & Tenure-Track & 3.73 & 2.92 & 5.20 & 4.72 & 4.81 & 4.64 & 3.55 \\
\hline & Non-Faculty $>6$ & 4.07 & 2.71 & 4.86 & 4.26 & 3.79 & 3.94 & 3.30 \\
\hline & Non-Faculty $<6$ & 4.73 & 3.42 & 5.28 & 4.94 & 4.74 & 4.81 & 3.85 \\
\hline \multirow{3}{*}{$\begin{array}{l}\text { All Faculty v. All Non- } \\
\text { Faculty }\end{array}$} & $D F$ & 672 & 698 & & 671 & 702 & 670 & 699 \\
\hline & $T$ & 0.50 & 3.39 & $\mathrm{~N} / \mathrm{A}$ & 4.43 & 7.37 & 3.80 & 4.90 \\
\hline & $P$ & 0.618 & $7.38 \mathrm{E}-04 * * *$ & & $1.12 \mathrm{E}-05^{* * *}$ & $4.94 \mathrm{E}-13 * * *$ & $1.57 \mathrm{E}-04 * * *$ & $1.17 \mathrm{E}-06^{* * * *}$ \\
\hline \multirow{3}{*}{ Tenure v. Tenure-Track } & $D F$ & 440 & 454 & 454 & 440 & 454 & 440 & 452 \\
\hline & $T$ & 4.46 & 4.86 & 5.16 & 3.67 & 3.93 & 1.47 & 6.08 \\
\hline & $P$ & $1.02 \mathrm{E}-05 * * *$ & $1.59 \mathrm{E}-06^{* * *}$ & $3.61 \mathrm{E}-07 * * *$ & $2.71 \mathrm{E}-04 * * *$ & $9.90 \mathrm{E}-05 * * *$ & 0.141 & $2.51 \mathrm{E}-09 * * *$ \\
\hline \multirow{3}{*}{$\begin{array}{l}\text { Tenure v. Non- } \\
\text { Faculty with }>6 \text { Years } \\
\text { Experience }\end{array}$} & $D F$ & 241 & 257 & & 241 & 256 & 241 & 257 \\
\hline & $T$ & 2.52 & 6.11 & N/A & 6.49 & 9.66 & 5.48 & 7.41 \\
\hline & $P$ & $0.013^{*}$ & $3.76 \mathrm{E}-09 * * *$ & & $4.80 \mathrm{E}-10 * * *$ & $4.95 \mathrm{E}-19 * * *$ & $1.05 \mathrm{E}-07 * * *$ & $1.85 \mathrm{E}-12 * * *$ \\
\hline \multirow{3}{*}{$\begin{array}{l}\text { Tenure-Track v. Non- } \\
\text { Faculty with }<6 \text { Years } \\
\text { Experience }\end{array}$} & $D F$ & 427 & 439 & & 430 & 444 & 429 & 440 \\
\hline & $T$ & 4.11 & 2.18 & N/A & 1.00 & 0.26 & 0.73 & 1.16 \\
\hline & $P$ & $4.83 \mathrm{E}-05^{* * *}$ & $0.030^{*}$ & & 0.317 & 0.797 & 0.464 & 0.246 \\
\hline${ }^{*} p<0.05 * * p<0.01 * * * p<0$ & & & & & & & & \\
\hline
\end{tabular}


scholarship through academic conferences ( $p=4.94 \mathrm{E}-13)$. Similarly, when asked to rank their agreement with the statement "Faculty status promotes the publication of quality, meaningful contributions to scholarship in library science and other fields," faculty librarians reported an average score of 4.80-significantly higher than the nonfaculty average of $4.26(p=1.57 \mathrm{E}-4)$. This indicates that faculty librarians believe their research has a positive impact on the academic world around them. Finally, when asked whether "faculty status is ultimately beneficial, directly or indirectly, to patrons," the difference between the average faculty response of 4.30 and the average nonfaculty response of 3.51 was statistically significant $(p=1.17 \mathrm{E}-6)$.

One faculty librarian summarized these points by commenting simply that "the most important reason for librarians having faculty status is that it provides opportunities and resources for them to contribute to the profession through presentations and publications. This allows librarians to stay current and ultimately results in better service to our patrons."

When these questions were analyzed for tenure trends, tenured librarians generally gave significantly higher responses than tenure-track librarians did. In fact, the only question that did not follow this trend was the previously discussed question regarding publication in library science and other fields, when there was no statistically significant difference. The overall trend suggests that tenured librarians value faculty status and tenure more highly than tenure-track librarians-perhaps because tenure-track librarians are still experiencing the stressors of the tenure process rather than enjoying its benefits.

Tenured and tenure-track responses were also compared to nonfaculty responses (broken down by years of experience to enable comparison between corresponding groups). When asked if faculty status benefits patrons, a statistically significant difference appeared between tenured librarians and experienced nonfaculty librarians ( $p=1.85 \mathrm{E}-12$ ). The tenured librarians reported an average of 4.73 , tending to agree that faculty status helps patrons, while experienced nonfaculty librarians reported slight disagreement at 3.30. A similar trend appeared in the statement that faculty status helps librarians' professional development ( $p=4.80 \mathrm{E}-10)$. Other comparisons along this line yielded more ambiguous results with no clear pattern for comparing tenure and tenure-track librarians to nonfaculty librarians.

\section{A Rebuttal to Arguments against Faculty Status}

Several questions measured librarians' opinions on the potential disadvantages of faculty status (see table 3). In response to the statement "The expectation for librarians with faculty status to 'publish or perish' negatively impacts a librarian's ability to perform his or her core duties," faculty and nonfaculty librarians reported average scores of 4.31 and 4.42 , respectively. These scores represent only moderate agreement and are not statistically significant when compared to each other. This suggests that it is not as difficult for librarians to manage competing priorities as many scholars believe. Universities do have high expectations for faculty members to publish; however, our results indicate that librarians with faculty status find it possible to balance their responsibilities.

In a survey statement claiming that the "duties and roles of librarians with faculty status are so different from those of teaching faculty that they cannot be accurately compared or evaluated," faculty and nonfaculty librarians responded with averages of 4.54 and 4.58 . However, when a statement suggested that the librarians' roles are so different from teaching faculties' that librarians should not receive faculty status, the averages for both groups dropped substantially. Faculty librarians reported an average agreement of 2.70, which was significantly lower than the nonfaculty average of 3.12 $(p=0.002)$. This question was the lowest average response for faculty librarians and the second lowest for nonfaculty librarians. This indicates that librarians believe that, 
although their roles differ from the roles of teaching faculty, librarian faculty status does have a viable place in the academic world and should not be eliminated from it.

The responses showed some similar results when analyzed for tenure trends. The question implying that librarians should not receive faculty status because of their role in the university, for example, showed almost identical responses between tenure-track librarians and less experienced nonfaculty librarians. Tenured librarians, however, showed a significantly lower response when compared to experienced nonfaculty librarians ( $p=1.47 \mathrm{E}-5)$ and to the tenure-track group $(p=1.10 \mathrm{E}-5)$. When asked about the negative impact of "publish or perish," the most notable significant difference appeared between tenured and tenure-track librarians, with tenure-track librarians reporting a higher level of agreement $(p=3.57 \mathrm{E}-8)$. It is true that tenure-track librarians are expected to meet strenuous requirements; however, many tenured librarians commented in free response that they felt their extra work had been well worth the benefits they now enjoy. One such librarian wrote, "For those of us that do eventually receive tenure, the positives outweigh the negatives. I have rarely heard a tenured librarian state that they are sorry they went through the process and would give it up."

\begin{tabular}{|c|c|c|c|c|}
\hline \multicolumn{5}{|c|}{$\begin{array}{c}\text { TABLE } 3 \\
\text { Arguments Against Faculty Status }\end{array}$} \\
\hline & Question & Q38 & Q44 & Q41 \\
\hline & & $\begin{array}{l}\text { Negative } \\
\text { Impact of } \\
\text { "Publish or } \\
\text { Perish" }\end{array}$ & $\begin{array}{c}\text { Different Duties } \\
\text { and Roles } \\
\text { than Teaching } \\
\text { Faculty }\end{array}$ & $\begin{array}{c}\text { Librarians Should } \\
\text { Not Be Faculty } \\
\text { Because of Role } \\
\text { Differences }\end{array}$ \\
\hline \multirow{6}{*}{$\begin{array}{l}\text { Averages (on } \\
\text { Likert scale of } \\
\text { 1-7) }\end{array}$} & All Faculty & 4.31 & 4.54 & 2.70 \\
\hline & All Non-Faculty & 4.42 & 4.58 & 3.12 \\
\hline & Tenure & 3.93 & 4.31 & 2.44 \\
\hline & Tenure-Track & 4.97 & 4.97 & 3.17 \\
\hline & Non-Faculty $>6$ & 4.40 & 4.71 & 3.18 \\
\hline & Non-Faculty $<6$ & 4.45 & 4.36 & 3.01 \\
\hline \multirow{3}{*}{$\begin{array}{l}\text { All Faculty v. All } \\
\text { Non-Faculty }\end{array}$} & DF & 669 & 669 & 670 \\
\hline & $\mathrm{T}$ & 0.77 & 0.27 & 3.05 \\
\hline & $\mathrm{P}$ & 0.444 & 0.790 & $0.002 * *$ \\
\hline \multirow{3}{*}{$\begin{array}{l}\text { Tenure v. Tenure- } \\
\text { Track }\end{array}$} & DF & 439 & 439 & 440 \\
\hline & $\mathrm{T}$ & 5.61 & 3.62 & 4.45 \\
\hline & $\mathrm{P}$ & $3.57 \mathrm{E}-08^{* * *}$ & $3.25 \mathrm{E}-04 * * *$ & $1.10 \mathrm{E}-05^{* * *}$ \\
\hline \multirow{3}{*}{$\begin{array}{l}\text { Tenure v. Non- } \\
\text { Faculty with >6 } \\
\text { Years Experience }\end{array}$} & DF & 241 & 240 & 241 \\
\hline & $\mathrm{T}$ & 2.47 & 2.17 & 4.42 \\
\hline & $\mathrm{P}$ & $0.014 *$ & $0.031^{*}$ & $1.47 \mathrm{E}-05 * * *$ \\
\hline \multirow{3}{*}{$\begin{array}{l}\text { Tenure-Track } \\
\text { v. Non-Faculty } \\
\text { with <6 Years } \\
\text { Experience }\end{array}$} & $\mathrm{DF}$ & 428 & 427 & 427 \\
\hline & $\mathrm{T}$ & 2.30 & 2.82 & 0.70 \\
\hline & $\mathrm{P}$ & $0.022 *$ & $0.005^{* *}$ & 0.483 \\
\hline${ }^{*} p<0.05 * * p<0.01 *$ & $*_{p}<0.001$ & & & \\
\hline
\end{tabular}




\section{Discussion}

These results indicate that faculty and nonfaculty librarians share some perceptions about faculty status, while disagreeing on certain other points. It is particularly interesting to examine librarians' perceptions about their relationship with teaching faculty. These perceptions are important, as feeling equal and valued on campus may better motivate librarians to fulfill the university's "educative mission." ${ }^{25}$ While both faculty and nonfaculty librarians acknowledged that faculty status can help them earn the respect of teaching faculty, neither group believed that teaching faculty consider them peers. One faculty librarian wrote in free response that "faculty status alone does not make teaching faculty respect us. Rather, it is our own attitudes and how we work with them that solidifies the relationship. Faculty status allows us to have a seat at the table; what we do when we get there is important." Being granted faculty status may be a decisive step in gaining more respect from teaching faculty-however, it is important for librarians to remember that the quality of their work and interactions with teaching faculty also affect this relationship.

When asked if faculty status increases the opportunity to participate in university governance, faculty librarians gave an average response of 5.71 and nonfaculty librarians gave an average response of 5.02. These are the highest averages either group reported in the study, meaning they strongly believe that administrators listen more attentively to faculty librarians. Hill further explains the importance of being involved in governance by saying that those librarians "are not left out when it comes to things like salary increases and policy formation." 26 In our study, one faculty librarian cited stronger relationships with teaching faculty as another benefit of participating in governance. This librarian made the following comment: "Faculty status has allowed me to participate actively in campus governance, and the benefits of the collegial relationships developed as a result of working collaboratively with faculty across the university have accrued back to the library. I have frequently drawn on these contacts to engage with other departments and colleges when pursuing library-related initiatives." Faculty status can strengthen librarians' voices and allow them to contribute to policy making, which is crucial in receiving input and validating their roles on campus. Governance participation can also promote collaboration between teaching faculty and librarians. All of these factors contribute to improving the university's quality and environment, making it important for administrators to consider awarding faculty status to librarians.

We conclude that faculty status helps librarians in other aspects of their work as well, which could in turn reinforce relations with teaching faculty. For example, faculty librarians marked strong agreement (an average response of 5.09) for the statement that faculty status helps them progress and develop professionally. (We add that attending and participating in conferences, as discussed previously, is a form of professional development and can be grouped here as well.) As librarians' professional development continues and their work quality improves, teaching faculty may over time notice the high caliber of university librarians. This would help the librarians gain more respect from the teaching faculty. Further, librarians' well-conducted research and publications could be influential in helping teaching faculty view librarians as peers. Since research is one of the areas where librarians' roles most resemble those held by teaching faculty, it is essential for faculty librarians to publish meaningful work that represents their merit as academic peers.

The librarians' free-response comments were as insightful into their perceptions as the averages for the value and agreement statements. In general, faculty librarians had more favorable opinions of faculty status than nonfaculty librarians, and tenured librarians had more favorable opinions than tenure-track librarians. The faculty librarians perceived status as, if not a solution, an important step toward better relations with 
teaching faculty. Many commented that perhaps having a PhD would be an additional factor in strengthening these relationships. They further acknowledged that faculty status can substantially increase participation in university governance and give greater opportunities to actively participate in academic conferences. Many also stated that their research teaches them skills that improve their customer service and librarianship.

Like faculty librarians, nonfaculty librarians did not believe that faculty status could make librarians equals in the eyes of the teaching faculty; however, many agreed that it could be a step in the right direction. Nonfaculty librarians said that faculty status increases a librarian's chances to be active in university governance, but they did not believe that research improves librarianship or customer service. Their general thought was that good librarianship comes from individual effort and dedication to the profession, rather than being propelled forward by faculty status or tenure.

Overall, it appears that the librarians to whom faculty status matters the most are those who already have it. Moreover, faculty librarians who have already achieved tenure generally had the most positive perceptions of faculty status. This trend appeared in questions regarding teaching faculty relations, professional development and publication, among others. In all of these cases, faculty librarians' high averages affirm that, at least among faculty librarians, faculty status comes with considerable perceived benefits. The results also indicated that nonfaculty librarians find faculty status more important to the profession as a whole than to them personally. Although they do not necessarily support faculty status, they still acknowledge the benefits it provides and recognize its place in the library profession.

\section{Limitations and Suggestions for Future Research}

This study is limited in that it focuses solely on librarian perceptions rather than factual evidence supporting or challenging faculty status. While the perceptions measured in this study help to analyze the faculty status question, it would also be useful to have side-by-side productivity data or information about librarian/faculty collaborations. The study is further limited because researchers cannot use two-tailed, two-sample t-tests to analyze each question. While it is possible to perform these tests on some questions, the evidence could more strongly support our conclusion if the tests could be performed for each survey question.

This study does not thoroughly address the stress of the tenure process for tenuretrack librarians; however, we recommend this as an area of future study for other researchers investigating the faculty status argument.

Other researchers may find it worthwhile to quantitatively determine if faculty status improves librarian productivity or collaboration quality between librarians and teaching faculty. They could also investigate how much more influence librarians with faculty status have on governance committees. Equitable pay is an additional concern when discussing faculty status because librarians in the past were unlikely to report that they had "equitable pay" with the teaching faculty. ${ }^{27}$ Because of this, it may be beneficial to further explore the perceptions and reality of librarian and teaching faculty salary differences.

Alternatively, it would be illuminating to research teaching faculties' perceptions into librarian faculty status - whether they view it as practical or state that it improves their relationship with librarians. This could either support or challenge this study's claim that librarian faculty status improves relationships with teaching faculty.

\section{Conclusion}

This study suggests the existence of perceived benefits and disadvantages of faculty status. It is important to consider these perceptions when attempting to determine 
if faculty status is right for a specific institution. If, as Biggs and Bernstein suggest, much of the importance of faculty status lies in its psychological worth, it follows that the perceived benefits and disadvantages of faculty status contribute greatly to that psychological import. Perhaps the most holistic way to evaluate faculty status would be a side-by-side comparison of these findings and a study that quantifies the nonpsychological benefits and disadvantages of faculty status.

While nonfaculty librarians value faculty status much less than faculty librarians do, even they seem to believe that it has its place in the profession. They perceive that having status increases participation on university governance and view this as one of its greatest benefits. Faculty librarians agree that this is a strong benefit and perceive several others as well. They believe that faculty status increases their chances to attend conferences, promotes the publication of quality research, and helps library patrons. Interestingly, both faculty and nonfaculty librarians believe that faculty status improves relationships with teaching faculty, although it can't balance that relationship evenly - this is probably the most valuable conclusion to be drawn from this study.

The results of this study, then, suggest that faculty status is psychologically important to many librarians and that it may improve relationships with teaching faculty. Similar to the purpose of Hoggan's literature study on librarian faculty status, perhaps these findings can "help individual librarians decide whether a faculty status position is right for them." ${ }^{28}$ This may assist recent MLS graduates and others in finding employment opportunities that fit their preferences and work style. It is important to encourage individual librarians to carefully consider the psychological benefits of faculty status and other factors when considering employment.

Individual institutions, meanwhile, may use this study to assess their policies concerning faculty status. There are other factors worthy of consideration, including salary differences, time faculty librarians devote to conducting research, and the mechanics of evaluating performance for tenure. However, this study is simply intended to help institutions evaluate the psychological component of the faculty status argument. With this in mind, these findings may serve to inform university administrators as they holistically determine whether faculty status is a good fit for their libraries.

\section{Notes}

1. Blaise Cronin, "The Mother of All Myths," Library Journal 126, no. 3 (2001): 144.

2. Ibid.

3. Shalu Gillum, "The True Benefit of Faculty Status for Academic Reference Librarians," Reference Librarian 51, no. 4 (2010): 322.

4. Ibid.

5. Paul Alan Wyss, "Library School Faculty Member Perceptions Regarding Faculty Status for Academic Librarians," College and Research Libraries (2010): 376.

6. Mary Biggs, "Sources of Tension and Conflict between Librarians and Faculty," Journal of Higher Education 52, no. 2 (1981): 193.

7. Janet Swan Hill, “Constant Vigilance, Babelfish, and Foot Surgery: Perspectives on Faculty Status and Tenure for Academic Librarians," portal: Libraries and the Academy 5, no. 1 (2005): 15.

8. Quinn Galbraith et al., "Who Publishes in Top-Tier Library Science Journals? An Analysis by Faculty Status and Tenure," College E Research Libraries 75, no. 5 (2014): 732.

9. W. Bede Mitchell and Mary Reichel, "Publish or Perish: A Dilemma for Academic Librarians?" College \& Research Libraries 60, no. 3 (1999): 240.

10. Beth J. Shapiro, "The Myths Surrounding Faculty Status for Librarians," College E Research Libraries News 54 (Nov. 1993): 562.

11. Ibid.

12. Devin Feldman and Susan Sciammarella, "Both Sides of the Looking Glass: Librarian and Teaching Faculty Perceptions of Librarianship at Six Community Colleges," College E Research Libraries 61, no. 6 (2000): 492. 
13. Wade R. Kotter, "Bridging the Great Divide: Improving Relations between Librarians and Classroom Faculty," Journal of Academic Librarianship 25, no. 4 (1999): 295.

14. Ibid.

15. Jacalyn Bryan, "The Question of Faculty Status for Academic Librarians," Library Review 56, no. 9 (2007): 782.

16. Biggs, "Sources of Tension and Conflict," 196.

17. Catherine Coker, Wyoma VanDuinkerken, and Stephen Bales, "Seeking Full Citizenship: A Defense of Tenure Faculty Status for Librarians," College \& Research Libraries 71 no. 5 (2010): 406-20.

18. Alan Bernstein, "Academic Librarians and Faculty Status: Mountain, Molehill or Mesa," Georgia Library Quarterly 46, no. 2 (2009): 14.

19. Ibid.

20. Shin Freedman, "A Pilot Study of Academic Librarians in New England," portal: Libraries and the Academy 14, no. 4 (Oct. 2014): 554.

21. "Association of College and Research Libraries Joint Statement on Faculty Status of College and University Librarians," American Library Association, available online at www.ala.org/acrl/ standards/jointstatementfaculty [accessed 5 June 2015].

22. Gillum, "The True Benefit of Faculty Status for Academic Reference Librarians," 321.

23. Ibid.

24. Quinn Galbraith, "Librarian Faculty Status and Tenure: A Quick Glance at Where We Stand" (unpublished manuscript, December 3, 2010), Microsoft Word Document.

25. Bernstein, "Academic Librarians and Faculty Status," 14.

26. Hill, "Constant Vigilance," 13.

27. Danielle Bodrero Hoggan, "Faculty Status for Librarians in Higher Education," portal: Libraries and the Academy 3, no. 3 (2003): 432.

28. Ibid. 


\begin{tabular}{lc}
\hline Question & Non-Faculty Alternative (if applicable) \\
\hline
\end{tabular}

How important is faculty status to you?

How important would faculty status be to you?

How important do you believe faculty status is to the library profession as a whole?

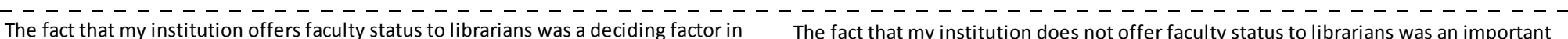

favor of accepting my current position. deciding factor in favor of accepting my current position.

Faculty status helps librarians earn the respect of teaching faculty.

- _ - -

The teaching faculty consider librarians peers because of library faculty status.

I have an increased opportunity to participate in university governance because of

faculty status.

Faculty status promotes the publication of quality, meaningful contributions to

scholarship in library science and other fields.

Faculty status is ultimately beneficial, directly or indirectly, to library patrons.

Faculty status helps librarians progress and develop professionally.

Faculty status provides opportunities and resources to participate in scholarship by

attending and/or presenting in academic conferences.

The expectation for librarians with faculty status to "publish or perish" negatively

impacts a librarian's ability to perform his or her core duties.

The duties and roles of librarians with faculty status are so different from those of

teaching faculty that they cannot be accurately compared or evaluated.

Librarians should not receive faculty status because their role in a university is to

support the teaching faculty's research, not to be actively engaged in their own research.

Librarians should not receive faculty status because the Master of Library Science degree

does not provide the same preparation for scholarship and research that the PhD does.

In general, librarians with faculty status do not receive better compensation than those

without faculty status.

Librarians with faculty status have an increased opportunity to participate in university

governance. 